\title{
Political and Aesthetic Equality in the Work of Jacques Rancière: Applying his Writing to Debates in Education and the Arts
}

Jane McDonnell

\section{Abstract}

Interest in the work of Jacques within educational philosophy has increased steadily over the past ten years. Readings of his 1991 work, The Ignorant Schoolmaster, have proved particularly popular amongst educationalists seeking to reconstruct from his work a theory of learning and teaching (see, e.g. Cornelissen, 2010). Bingham and Biesta's (2011) contribution has been an interesting addition to the field. Their work goes beyond purely pedagogical readings of Rancière's philosophy (both in this text and elsewhere) to emphasise the critique of a 'society pedagogicized' in his work. This term refers to the situation in which people's political experience is constantly in need of explaining back to them (often by historians, sociologists and political scientists). Rancière's writing has also been the subject of intense interest amongst art theorists. Bishop (2012) for example, has applied his philosophy to theorise the resurgence, internationally, of interest in participatory and collaborative art as the latest form of boundary crossing between 'art' and 'non-art' in contemporary practice - particularly in innovative 'pedagogic arts projects'. In arts education, Rancière's thought has been variously employed to re-examine the possibility of a post-Kantian 'aesthetic education' (de Boever, 2011); to argue for art as a form of disruptive pedagogy (Atkinson, 2012) and to offer a reappraisal of the aesthetics of democratic and emancipatory education (Lewis 2012; 2013; McDonnell, 2014a). In this paper, I build on the above contributions to address two key questions. Firstly, what can Rancière's work add to a number of key debates within education and the arts? Secondlly, in applying Rancière's work to these questions, what can be learnt about the way in which his work is being taken up within the field?The paper addresses these questions via a critical reading of some of Rancière's most notable contributions in both political philosophy and aesthetics. This critique is combined with a discussion of research literature in three key areas of debate within arts education, namely; the challenge of contemporary art within schools and galleries, the role of art and aesthetics within democratic education. In each case, I illustrate how the emphasis on equality - both aesthetic and political - in Rancière's work offer some fresh perspectives on existing debates.

\section{Introduction}

Interest in the work of Jacques Rancière within educational philosophy has reached something of a highpoint in recent years, with readings of his 1991 text, The Ignorant Schoolmaster: Five lessons on intellectual emancipation, proving particularly popular amongst those seeking to reconstruct from his work a theory of learning and teaching 
(see, e.g. Cornelissen, 2010; Friedrich et al., 2010). Bingham and Biesta's (2011) book, Jacques Rancière: Education, truth, emancipation, is a particularly interesting contribution in this respect, doing much to move discussion beyond purely pedagogic readings of Rancière's work to highlight its broader implications for education, society and the social sciences. In particular, their work emphasises the critique of a 'society pedagogicised' in Rancière's writing, in which people's social, cultural and political life is constantly in need of being explained back to them-often by sociologists, historians and political scientists. Indeed, Rancière's account of Joseph Jacotot's experiences of teaching French to Flemish students, whose language he did not know, can be read at least in part as a metaphor or allegory for the explicatory logic dominating society and politics as much as a manifesto for a particular kind of non-stultifying pedagogy.

In the field of arts education too, there has been sustained interest in Rancière's work, with his philosophy being taken up to outline ways of thinking about art as a kind of disruptive pedagogy (see, e.g. Atkinson, 2012). Lewis (2012) has offered a new contribution to thinking in emancipatory education via a (re)reading of both Rancière and Freire that also engages with questions about the aesthetics and artistry of teaching itself. Others have applied Rancière's work to renewed discussion of the possibility of an 'aesthetic education' (see, e.g. de Boever, 2011). In my own work (McDonnell, 2014a)I have employed insights from Rancière's writing to tackle the complexity of the relationships amongst democracy, art and education and their significance for educational theory and practice. In particular, I have argued that Rancière's work allows us to imagine the role of art in the relationship between education and democracy differently (reference removed) via a reading of Biesta $(2006,2010)$. Specifically, Rancière's work allows us to see the important moments of democratic subjectivity that form part of Biesta's (2010) alternative view of democratic learning (learning from the experience of democratic subjectivity or the lack thereof) as aesthetic moments, which are also sometimes made possible through art. Here, my work aligns with Lewis' (2013) exploration of the implications of Rancière's 'aesthetic regime' for democratic education, arguing that democratic education itself can and ought to be a site of aesthetic and political disruption. As well as creating the space for such aesthetic moments of democratic subjectivity to emerge, democratic education can also support learning from these moments-both within educational settings and beyond.

In this paper, I wish in part to reiterate these points but also to set this argument about democratic education within the context of other debates in both arts education and the use of art within community and adult education. I do so by addressing three 'problems' or debates in these areas, namely; the challenge of postmodernism and contemporary art for arts education in schools and galleries, what I have elsewhere referred to as the 'aesthetic deficit' in democratic education McDonnell, in press), and the balance between aesthetic and other-social, political and educational-aims in 
new forms of collaborative and participatory art. I am less concerned here with the aesthetics of teaching itself, than with how Rancière's work on politics and aesthetics can offer innovative and refreshing perspectives on these debates. In doing so, I also hope to illustrate the centrality of equality in Rancière's work-politically, between people (Rancière, 2006) but also aesthetically, between artistic genres, styles and subject matter (Rancière, 2004, 2007) - and therefore of any 'Rancierian' reading of such debates.

\section{Contemporary Art In Schools And Gallery Education}

The first of the debates I wish to address is the challenge posed to arts education in schools and galleries by contemporary art. In the early part of this century, Burgess and Addison (2004), wrote a seminal text on the challenges that contemporary art brings to schools, mounting a strong defence for the continued engagement with such art in the classroom. In doing so, they highlighted concerns such as the propensity of contemporary art to address social and political issues explicitly, often in a transgressive way, and its 'unexpected or radical materials, means of production and dissemination' (Burgess and Addison, 2004, p. 15). The authors illustrate well how some of the characteristics of contemporary art (including its pre-occupation with text and mixing of materials, high and low art forms) are often conceived as incompatible with the modernist project of art in schools. Heavily influenced by Herbert Read's philosophy of education-through-art, the arts education community has been characterised by a commitment to creative self-expression, transformation at both an individual and societal level, and (somewhat paradoxically) traditional skills and craft. ${ }^{1}$ For Burgess and Addison, this involves the rather interesting juxtaposition of students' self-expression with, 'cultural reproduction' and, 'the perpetuation of "traditional skills"' (2004, p. 20). They argue that ignoring contemporary art in schools, 'denies it the role it might have in educating students to challenge hegemonic structures' (2004, p. 16).

Elsewhere, in gallery education, similar arguments about the educational value of contemporary art have been made. Writing on the contemporary gallery space as a prime location for engaging students, Illeris (2005) draws comparisons between the characteristics of contemporary art itself-in the form of, 'the hook', 'the experience of otherness', 'social interaction' and 'meta-reflection' (2005, p. 237) and the kinds of thought patterns and modes of engagement with visual culture that characterise young people in the 21st century. Paradoxically, whilst emphasising the contingent and relational aspects of contemporary art, Illeris (2005) adopts quite an essentialist view of young people, drawn primarily from research in the fields of youth studies and cognitive psychology and does not explicitly engage with the educational process or learning itself (2005, pp. 233-234). As such, Illeris' (2005) argument risks both eliding the variety of young people's experiences and presenting the contemporary art gallery 
as a kind of unalloyed good, or magic bullet, for solving the perceived problem of young people's lack of engagement with art.

Whilst it does not represent the whole of gallery education, Illeris' (2005) argument does, however, illustrate how prominent arguments within the field make claims about the value of contemporary art based on rather essentialist assumptions. Equally, though making a different case, Burgess and Addison's (2004) argument for contemporary art in schools adopts some essentialist assumptions about the nature of contemporary art and its alliance with cultural forms familiar to young people from their lives outside school. In highlighting why contemporary art is problematic, they also give credence to claims about purity and craft that often emanate from modernist and conservative quarters. Though written over a decade ago, discussion of the balance between traditional skills and self-expression, and its juxtaposition to what is sometimes seen as the overly commercial and self-indulgent world of contemporary art remain areas of live debate within the arts education research community.

There are at least two difficulties with this framing of the challenge that postmodernsim and contemporary art presents for schools and gallery education, and the solutions presented. The first is that the 'problem' of contemporary art is located in the 'newness' and innovation of such forms. Underlying the claims and counterclaims outlined above, is an assumption that contemporary art is radically different from that which preceded it. The solutions proffered-both the implied solution of 'not bothering' with contemporary art in the classroom, and the contrary position of harnessing its unique qualities to engage young people-lead to a second difficulty. That is that they marshal rather essentialist arguments for use of particular artistic trends, patterns and forms in educational contexts. We are left with a situation in which contemporary art is seen either as a threat to familiar constructs of school art or, conversely, the saviour of arts education for an irrevocably altered generation of young people. These two difficulties then lead to a third problem of an inherent inequality assumed between various art forms, between the various purposes of arts education and perhaps even between the ability of older and newer generations of students to comprehend them. It is this assumption of inequality that I would argue Rancière's work has the particular power to challenge.

\section{Rancière's Artistic Regimes And Contemporary Art}

One way of illustrating this is via a discussion of Rancière's intervention in the debate over words and images in contemporary visual art, and the place of this within his broader concept of artistic regimes. The problem identified in this debate is often conceived as the proliferation (or even invasion) of words within contemporary visual art. This is perhaps best exemplified in the ludic wordplay of many contemporary artists, or in the long tracts of explanatory text that often accompany the art 'itself' in contemporary galleries. Rancière's writing on this debate is particularly valuable 
because he offers a radical critique of the very distinction between the visual and the textual in art, upon which such debates are premised. Writing on the nature of, 'the image', Rancière claims (or perhaps reminds us) that artistic images have never solely been a visual matter, and that pure form (e.g. paint on canvas, charcoal on paper or sculpted clay) is a very modernist idea that seeks to preserve the special status of art via an appeal to materials. Rather, he argues that the creation of an 'image' has always involved the conjuring up of a likeness, which can be achieved with all sorts of materials, and always involves a dual operation of visual and textual elements. What is often seen as the problem of, 'too many words' (Rancière, 2007, p. 69) in contemporary art is, for Rancière, not a replacement of the visual with the textual, or an invasion of words into the pure sphere of art, but rather a new arrangement of the relationship between the two in the creation of images. Where once the visual offered a representation of the textual-the depiction of a shared story (often taken from Judeo-Christian scripture or classical mythology), the 'story' (in the forms of description, explanation or account) now often makes sense of the visual. This 'equality' of sorts between what is seen and what is 'read' is one of the key themes in Rancière's take on the ruptures that have defined the history of western art.

This point is particularly well illustrated in Rancière's discussion of a critique of Gaugin's 1888 painting, Vision du Sermon (or, La Lutte de Jacob avec l'Ange) written by Albert Aurier in 1890. Rancière is particularly interested in the significance of Aurier's critical essay within art history, as a precursor to, or inauguration of, abstract painting; as he describes it, the text is, 'a manifesto for a new kind of painting, a painting that no longer represents reality but translates ideas into symbols' $(2007, \mathrm{p}$. 83). The painting depicts a number of women in a field, wearing headdresses and with bowed heads, in the foreground of the picture. In the background a representation of the biblical story of Jabob's struggle with the angel, from the book of Genesis, can be seen. Rancière argues that Aurier's critique transforms certain elements of the painting to make it work in abstract terms. This transformation itself relies on a number of other assumed texts within the painting, i.e. the biblical text telling the story of Jacob, the spoken, 'text' of the preacher's sermon, and the text of the painting's title that signifies both. Aurier's critique alludes to these other texts to tell the story of how the painting works; the depiction of Jacob's struggle conjures up the voice of the preacher, which in turn conjures up another painting that is not 'really' there, the painting of a rural church, indicated by the women's Breton headdresses and bowed heads.

Here, Rancière deftly illustrates how textuality is at the heart of both the painting and the account that would make it a crucial step in the emergence of abstract art. Within the painting itself, a text is already implied, and a familiarity with it is assumed; viewers need to know the story of Jacob wrestling the angel in order to understand what is being depicted. Beyond this, Aurier's text, 'writes' another image onto the canvas, that 
of the Breton church, and in doing so, introduces abstraction; the women do not literally see Jacob's struggle in the field beyond but 'see', in their minds' eye, the image conjured by the preacher's voice. As Rancière puts it, 'the description is a substitution. It replaces one scene of speech by another. It does away with the story with which the representative painting was in harmony; and it does away with the scene of speech to which the spatial depth was adjusted' (2007, p. 85).

This reference to 'representative painting' highlights a crucial aspect of Rancière's writing on aesthetics, i.e. the transition from a 'representative' to an 'aesthetic' regime of art (Rancière, 2007, p. 76). These terms define his conception of how the arrangement of the relationship between art and life as well as the relationship between different art forms, shifted around the turn of the 19th century, i.e. his particular take on what is often more commonly described as the advent of modernity in art. For Rancière, the aesthetic regime emerged as a rupture with the existing, 'representative' regime, which originated in Aristotle's delineation of appropriate art forms for appropriate subject matter, and was later instituted in the 'beaux arts' or 'fine arts' tradition of Europe (Rancière, 2007, p. 73). On this account, both modernist and postmodernist art fall within the aesthetic regime, and the dissatisfaction expressed about the proliferation of text in art becomes an expression of the modernist insistence on the purity of form, often linked to abstractionism in painting; 'the modernity that claims to vouchsafe each art its autonomy and painting its peculiar surface' $(2007$, p. 87). This in itself he sees as part of an attempt to defend the singularity of art against a maelstrom of other, social and political forms of doing, being and thinking in the newfound absence of a system of equivalences that would govern art's relationship to them (2007, pp. 120-121).

Whilst Rancière locates these regimes of art within historical context, he does not imply a teleological or progressive transition from one to the other. In the same text, he offers a critique of Lyotard's claim that postmodernist, 'anti-representative' art is the logical end point in a world in which some things, following the Holocaust, have become, 'unrepresentable' (Rancière, 2007, pp. 109-138). Rancière argues that such interpretations are misguided in their understanding of what it means to represent. The 'representative' regime for Rancière is not characterised by representation per se but by a very specific, Aristotelian set of relationships regulating that representation. This regime at the same time kept the 'arts' in a stable and somewhat distant relationship to real life. For Rancière, representation is equally possible within the aesthetic regime, even of the Holocaust. ${ }^{2}$ Perhaps the most important points to note here are that Rancière places concern over the purity of form in visual art within the art historical context of a modernist attempt to retain the singularity of art in the face of its potential erasure by 'real life'. Furthermore, he does so in a way that offers an alternative and less deterministic history of art than that of Lyotard. This is again illustrated in Rancière's (2009) discussion of shifts within contemporary art, in which 
he charts the ways in which the staging of the dialiectic clash between art and 'nonart' has shifted over time. Here, he argues against the claims of 'postmodernist polemicists' such as Lyotard and Adorno that a definitve and 'radical shift from modernity to postmodernity' (2009, p. 40) occurred in the 1960s. Rancière here illustrates how fears of the invasion of trivial and commercial elements into the art space are also misplaced; '[a]s soon as art was constituted as a specific sphere of existence, at the beginning of the nineteenth century, its products began to fall into the trivality of reproduction, commerce, and commodity.' (2009, p. 43).

Returning to the question of the challenge that contemporary art poses to arts educationin schools and galleries, the most obvious point to be made here is that some of the essentialist assumptions about fundamental differences between contemporary and earlier art forms (and deterministic arguments that stem from these) are erroneous or at least highly questionable on a 'Rancierian' reading. Contemporary art does not need to be defended from modernist and traditionalist accusations about its overly textual and political nature (since art has always been such), or its use of 'unexpected or radical materials, means of production and dissemination' (Burgess and Addison, 2004, p. 15). Neither is it the answer to the problems of an 'unreachable' generation; there is nothing uniquely special, powerful or 'other' about contemporary art that will perform a magic trick in young people's minds when they enter a contemporary art gallery. The presence of many textual and political elements in contemporary art does not mark the end of any pure artistic experience, unmediated by the sullying influence of words. There are simply a whole range of artistic practices, which, freed from the constraints of a hierarchical logic endorsing the use of certain forms for certain subjects, make arrangements and rearrangements of forms and ideas in various ways. Here it is worth emphasising the centrality of equality in Rancière's writing. Not only is there equality between the visual and the textual, but also between the various forms of production, once governed by a strict hierarchy of correspondences in a 'representative' regime of 'the arts' but now circulating freely and competing on equal terms in an aesthetic regime of 'art'.

This calls into question the claims of arts educators who wish to preserve a pure sphere concerned only with art 'itself' - both for its redemptive power and for its preservation of traditional skills and craft. The paradoxical coupling of modernist and conservative concerns that this position entails has already been adequately critiqued by Burgess and Addison (2004). But Rancière's work implies also that the purity such educators seek was never really there-the art of painting, for example, has never simply been a matter of pigment on canvas. Equally, however, it does not validate the claims of those educators who see in contemporary art an entirely new and uniquely powerful answer to the problem of engaging young people with art in the first place. Seen from a Rancierian perspective, both positions rest on false assumptions about 
the purity of art and the redemptive power of the 'new'. That this 'newness' is in part an explicit engagement with politics raises a further question about the politics of arts education. This is a question I return to in the third part of the paper but now I wish to address a related but different question about the role of art in political and democratic education.

\section{Art and The 'Aesthetic Deficit' In Democratic Education}

If the above debates indicate the problematic nature of politics in both art and art education, then the following discussion is intended to address some of the complexity of defining the role of art in political-specifically democratic-education. Elsewhere, I have argued that there is an 'aesthetic deficit' in democratic education, which, in the UK at least, has centered on providing young people with the cognitive skills, as well as the knowledge and understanding, necessary for participation in mainstream politics and democratic processes (McDonnell, 2016). In particular, I have noted the emphasis on rational discussion and debate within both state-sanctioned political education (most notably citizenship education in the UK) and more alternative traditions such as democratic schooling and its recent incorporation within mainstream education via the student voice movement (see Rudduck and Fielding, 2006 for a critique of this). I have further argued that it is important to pay greater attention, in educational research, to the aesthetic dimension of democratic action, practice and subjectivity, and the role of art within this (McDonnell, 2014b). To study how young people learn about, for and from democracy, it seems important to consider the artistic and aesthetic dimensions of their democratic and political experiences. There is also a broader point here about how we conceive of political literacy, which has become a significant element of democratic education both in schools and public education campaigns targeted at young people. I would argue that there needs to be much greater recognition of the aesthetic dimension of such literacy in democratic and political education, including an awareness of its 'literariness' and its relationship to literature, fiction and the creative arts. Here, I wish to address this issue by considering one element of Rancière's work in particular; his concept of 'fiction' in his writing on the relationship between politics and literature.

\section{Politics and Literature In Rancière's Aesthetic Regime of Art}

Rancière sees $19^{\text {th }}$ century literature, and the modernist novel in particular, as a key juncture in the emergence of an aesthetic regime of art. As outlined above, this caused a rupture with the representative regime that governed the articulation of specific subject matter with specific artistic genres, including the written art of poetry with the actions of monarchs and generals (Rancière, 2004, 2009). Equality is a central feature in Rancière's discussion here-both the literary equality of artistic forms and the political equality of subject matter, as well as the equality implied in the open circulation of literature itself. It is not possible to understand this without also 
engaging with Rancière's concept of the 'partage du sensible' or 'distribution of the sensible' (2004, p. 12), which he refers to as, 'the system of a priori forms determining what presents itself to sense experience' (2004, p. 13). For Rancière, this distribution (or 'partition' as it is also sometimes translated, more accurately reflecting the conflict inherent in the arrangement and re-arrangement of such forms), comes before the specific arrangements of both political government and the arts. This is also, for Rancière, the terrain on which politics and aesthetics are related since, '[p]olitics revolves around what is seen and what can be said about it, around who has the ability to see and the talent to speak, around the properties of spaces and the possibilities of time' (2004, p. 13). Since the original democratic rupture in Athens, this has also always been a contested terrain. Rancière is especially interested in the role of literature in the disruption and re-arrangement of those relationships that in many ways instigated the shift from a representative to an aesthetic regime of art.

Rancière refers to the modernist novel in particular, and its concerns with descriptive detail over plot, to illustrate how the duality and equality of the visual and textual applies as much to literature as it does to innovation in the visual arts. In discussion of a number of texts, particularly Flaubert's Madame Bovary (2004, 2007, 2008), Rancière illustrates how, with the modernist novel, the description of detail and evocation of the senses became the important task of art. This also ushered in a certain equality, by elevating the minutiae of everyday life to the main subject matter of literature. With the advent of the aesthetic regime, art became paradoxically singular ('art' not 'the arts') and yet automatically political (no longer cordoned off as a separate sphere of activity). For Rancière then, the modernist novel represents both an artistic and a political phenomenon; in Flaubert's hands, it becomes a modernist attempt to establish the 'purity' of art and to keep democracy (or the bourgeois approximation of it with social and cultural excesses of desire, appetite and will) in its place. Emma Bovary, he argues, is made to stand in for "the "democratic" equivalence of any source of excitement and any form of pleasure' $(2008$, p. 237) which was considered to be the 'disease' of the age amongst the 'notables and learned persons' (2008, p. 235) of the day:

Needless to say, they had efficiently worked during the French Second Republic (1848-51) to crush the threat of democratic anarchy (...) political democracy, they said, had been crushed, but there was a new, far more radical uprising of democracy that no policy, no army could tear down: the uprising of the multitude of aspirations and desires, cropping up everywhere in all the pores of modern society' (2008, pp. 235-236)

It is important to note that Rancière also acknowledges different responses to this new aesthetic and political situation within literature itself. In Balzac's hands, he argues, the social and political import of novelistic literature is privileged over the 
purity of art (2008, p. 238) but in both cases, the approximation of the social and cultural life of the masses with democracy is made possible via a 'wider redistribution of the sensible, which has it that there is no difference between two humanities, between the men dedicated to noble actions and the refined passions of men and women dedicated to "practical life"' (2008, p. 238). It is this redistribution-or repartition-of the sensible that marks a significant political moment. And it is the equality of subject matter within literature, as well as the equality implicit in the detailed description of the minutiae of everyday life, that allies it with political equality. Whilst Rancière's argument here relates particularly to literature in France in the wake of the French revolution, he also refers to work from English literature to illustrate other shifts, such as the emergence of the 'postmodern' novel. ${ }^{3}$

The precise nature of the relationship between art and politics remains elusive in Rancière's writing. Certainly, he does not ally the shift in artistic regimes to any particular political project. Rather he notes that as a consequence of the emergence of an aesthetic regime, art practices and products can always be taken up and used by any political project. But there is another duality present in his characterisation of literature-between activity and passivity - that is crucial to his understanding of the political import of literature. In The Politics of Aesthetics (2004), Rancière argues that within the new, aesthetic regime, both art and politics create 'fictions' that offer up what he describes as 'channels for subjectivization', i.e. new ways of thinking, being and doing. This point is reiterated in his (2009) claim that '[a]rt does not do politics by reaching the real. It does it by inventing fictions that challenge the existing distribution of the real and the fictional' $(2009$, p. 49).

Here, Rancière's writing about art converges with his political philosophy. Particularly in Hatred of Democracy, Rancière characterises democracy as a fluid and dynamic movement or 'logic' (2006, p. 55), which occurs via a process of political subjectification, at the moment in which people enact or embody a new form of political subjectivity, thus disrupting the existing political order. Such disruptions are what Rancière refers to as genuine 'politics' (2006, p. 49) ${ }^{4}$ pointing to the civil rights movement in the United States of America by way of example (2006, p. 61). At one point, Rancière suggests that literature can contribute to the democratic process by creating channels for subjectivisation that disrupt rather than unify. Referring to the importance of 'disincorporation' (2004, p. 40), he argues that, 'man is a political animal because he is a literary animal who lets himself be diverted from his "natural" purpose by the power of words' (2004, p. 39).

Three important points seem worthy of attention here. Firstly, Rancière sees art and politics as being fundamentally related at the level of a 'distribution' or 'partition' of the sensible, which comes prior to any political project or regime of art and is always the site of conflict and disagreement. Secondly, art (as illustrated via the discussion of 
literature and the emergence of the novel as a new art form in particular) cannot be separated from 'real life', including political life. In Rancière's view, the 'aesthetic regime' that has been dominant since modernity creates a situation in which both art and politics offer 'fictions' that contribute to democracy because of their shared interest in-or practice of-equality; the equality of any human being with any other human being and the equality of any subject matter with any other. Thirdly, the political acts that make up democracy involve an aesthetic rupture in the actual distribution or partition of the sensible and democracy can therefore be experienced aesthetically. Whilst Rancière's work is premised on a very specific understanding of both democracy and art, these contributions are particularly helpful for thinking through the relationship between art and democratic education.

I have previously argued that such insights make it important to pay attention to the aesthetic dimensions of young people's political participation and democratic learning (McDonnell, 2014a). Building on Biesta's $(2006,2010)$ arguments about the possibility of a democratic education that supports moments of democratic subjectivity as they emerge, and encourages reflection upon these (as well as on times when such subjectivity has not been possible), I have argued in particular that Rancière's work allows us to see such moments as already deeply aesthetic and often facilitated through art (McDonnell, 2014a) Lewis (2013) offers a similar analysis of Rancière's work to argue that democratic education ought to be a space in which disruptions and reconfigurations of the distribution of the sensible-at once both aesthetic and political-can occur. I would add that democratic education also encompasses the process of supporting people in their reflection on and learning from experiences of such disruptions in their everyday lives, outside the formal educational sphere. I also wish to draw attention here to the 'literariness' of such moments and to suggest that this opens up new ways of conceiving political literacy within democratic education.

\section{Rancière And The 'Rehabilitation Of The Aesthetic'?}

The relationship between aesthetics and politics in Rancière's work is also relevant to the final 'problem' or debate I wish to address in this paper, i.e. the way in which art can and does play a role within community education. Often of a political and emancipatory character (see, e.g. Evritt, 2001; The Community Arts Working Party, 1974) community education also often makes use of arts projects and activities and has strong ties to the community arts movement (see, e.g. Houston, 2006). One important question raised in this sphere relates to the appropriate balance between artistic and other priorities in community-based education and arts projects. The work of Bishop (2012) has been influential in this area. Writing on the resurgence of participatory and collaborative art forms in recent years, Bishop (2012) argues that socially engaged, participatory art has become the new norm for contemporary 
artistic practice, as it increasingly makes incursions into new territories and genresfrom theatre and performance to education.

Bishop (2012) aligns current trends in contemporary artistic practice to the emergence of an aesthetic regime in which the boundary between 'art' and 'life' is perpetually contested. In an echo of earlier debates about the proliferation of text in visual art, and the mixing of high and low art forms in 'postmodern' art, she further argues that this kind of art practice has come to be valued more-and sometimes exclusively-for its social and political significance rather than its aesthetic qualities. She sees in Rancière's work the possibility of 'rehabilitating the aesthetic' for contemporary art and appeals to an interpretation of his 2009 text, The Emancipated Spectator, to argue that concentration on the social and political in art is necessarily limited, since, '[c]ontemporary art has arguably become a mass-cultural practice, but art requires a spectator' (2012, p. 190). In her framing of both the problem and the solution, Bishop's argument rests in part on a reading of Rancière.

An important point to note within this argument is Bishop's (2012) account of how the educational dimensions of collaborative and participatory art have shifted over time. Tracing a history of artists' social engagement from the community arts movement of the 1960s and 1970s, to the participatory work of current artists, Bishop (2012) notes a contrast between the overtly educational agenda of the community arts movement and artists work that now often takes the form of 'pedagogic art projects' (2012, p. 241), as 'both artists and curators have become increasingly engaged in projects that appropriate the tropes of education as both a method and a form' (2012, p. 241). However, when discussing how the educational and artistic direction of such projects might most helpfully be negotiated, she turns to Freire rather than Rancière. She writes, '[u]nlike Rancière, it is significant that Freire maintains that hierarchy can never be entirely erased (...) critical pedagogy retains authority, but not authoritarianism (...) Freire's framework applies equally to the history of participatory art' (Bishop, 2012, p. 266). In addition, she argues that 'the best examples [of such projects] provide "programme and content" rather than a utopian space of undirected, open collaboration' (2012, p. 267).

The issue of how art is used within community education, and the blurring of the boundaries between art and community projects that have an educational and political dimension is a real and interesting one. Bishop's (2012) intervention on the problematic balance between aesthetic, and other, social, political and educational objectives within such projects is also significant and has gained currency in the literature on contemporary art and aesthetics. It is valuable to the extent that it addresses the interconnectedness of art and non-art and life in contemporary practice, taking seriously Rancière's characterisation of the aesthetic regime. Furthermore, it does so whilst emphasising the historical contingency of the current 
resurgence in participatory and collaborative art. In a sense, Bishop's (2012) argument can be read as an extension of Rancière's discussions of the 'mixing' of forms, of high and low art, and of art and life-the continuous 'playing on the boundary and the absence of boundary between art and non-art' $(2009$, p. 42) that is as old as the aesthetic regime or art. As Rancière (2009, p. 49) argues, 'doing art means displacing the borders of art' and Bishop's (2012) account of the newest participatory turn in contemporary art illustrates this very well. However, Bishop's (2012) reading of Rancière is also problematic. Firstly, and perhaps most notably, are the conservative and elitist overtones that the concept of 'rehabilitating the aesthetic' carries with it. Just as 'you cannot oppose an epoch of the celebration of high art to an epoch of the trivialization or parody of high art' $(2009$, p. 43), it seems unreasonable to oppose the properly aesthetic and artistic aims of art to its political, social and educational dimensions within any Rancierian reading of the 'problem'.

Perhaps even more significant, however, is that Bishop's (2012) interpretation of the most successful 'pedagogic art projects' is based on a critical pedagogy rooted in Freire and the concept of 'authority' (2012, p. 266). Here our discussion returns to interpretations of Rancière's work for education and pedagogy, based on his arguments about intellectual emancipation found in The Ignorant Schoolmaster (1991). Lewis' (2012) work is particularly helpful here, offering a reading of the work of both Rancière and Freire to rethink critical pedagogy, and drawing a distinction between the 'beautiful solidarity' of Freire's thought and the 'sublime uncertainty' that Rancière's writing invokes (2012, p. 66). An alternative, egalitarian reading of Rancière's contribution to debates on critical pedagogy can also be found in Bingham and Biesta's (2011) work, based not on the principle of authority or of a truth to be arrived at but on the principle of equality to be tested and verified. What is particularly significant is that Bishop's (2012) endorsement of a Freireian approach to art and critical pedagogy can easily be read as following and contributing to the logic of a 'society pedagogicized' (Rancière, 1991) rather than challenging it.

\section{Conclusion}

In this paper, I have argued that Rancière's work, and particularly his emphasis on the principle of equality in both political philosophy and aesthetics, allows us to tackle three important debates in the framing of the relationships amongst art, education and politics, from a fresh perspective. In arts education, his insistence on the illusion of the purity of form in visual art helps to debunk essentialist arguments that frame contemporary art as either the death knell for traditional skills and self-expression, or a recipe for re-engaging a somehow differently wired generation of young people. In doing so, it opens up the possibility for more nuanced and creative responses to innovative artistic practice and its place in education. Read as an illustration of the deeply aesthetic nature of politics and an insistence on equality as the key principle 
for democratic action, Rancière's work can also lead to new ways of thinking about the nature and purpose of democratic education, and the role of art within it. I have argued, along with Lewis (2013) that democratic education can be a space for the disruption and reconfiguration of the aesthetic basis upon which all politics rests. I would argue (via Biesta 2006, 2010) that a further purpose for democratic education based on a Rancierian reading of aesthetics and politics is supporting young people in their reflection on and learning from such moments of aesthetic disruption - both within formal education and in everyday life, often in relation to the arts. Finally, I have argued, contra Bishop (2012), that rather than offering a 'rehabilitation of the aesthetic', Rancière's writing in fact offers a more radical reading of the interrelationships between art and life that allow for an approach to arts-based community and education projects that does not follow the logic of a 'society pedagogicized' but begins with an assumption of equality. Whilst I have addressed these three debates as discrete 'problems', all highlight the importance of continuing to pay attention to Rancière's work when thinking through the relationships amongst art, politics and education and to do so in a way that makes equality-in its various forms - the central premise.

\section{References}

Abbs, P. (2003) Against the Flow: Education, the Arts and Postmodern Culture (London, Routledge Falmer).

Atkinson, D. (2012) Contemporary Art And Art In Education: The New, Emancipation And Truth, International Journal of Art \& Design Education, 31(1), pp. 5-18.

Biesta, G. (2010) Beyond Learning: Democratic Education For A Human Future (London, Routledge).

Biesta, G. (2006) How To Exist Politically And Learn From It: Hannah Arendt And The Problem Of Democratic Education, Teachers College Record, 112(2), pp. 556-575.

Bingham, C. and Biesta, G. (2011) Jacques Rancière: Education, Truth, Emancipation (London, Continuum).

Bishop, C. (2012) Artificial Hells: Participatory Art And The Politics Of Spectatorship (London, Virago).

de Boever, A. (2011) The Philosophy Of (Aesthetic) Education, in: Smith, J. and Weisser, A. (eds.) Everything is in Everything. Between Intellectual Emancipation And Aesthetic Education. Zurich, JPR/Ringier).

Burgess, L. and Addison, N. (2004) Contemporary Art In Schools: Why Bother? in: R. Hickman (ed.) Art education 11-18 (2nd edition) (London, Continuum). 
The Community Arts Working Party (1974). The Report of the Community Arts Working Party (London, The Arts Council of Great Britain).

Cornelisson, G. (2010) The Public Role Of Teaching: To Keep The Door Closed, Educational Philosophy and Theory, 42(5-6), pp. 523-539.

Everitt, A. (2001). Culture and Citizenship. In Crick, B. (ed.), Towards a Citizenship Culture (Oxford, Blackwell).

Freidrich, D., Jaastad, B. and Popkewitz, T. (2010) Democratic Education: An (Im)Possibiity That Yet Remains To Come, Educational Philosophy and Theory, 42(5-6), pp. 571-587.

Houston, S. (2005). Participation in Community Dance: A Road To Empowerment And Transformation? New Theatre Quarterly, 21(2), pp. 166-177.

Illeris, H. (2005) Young People And Contemporary Arts, International Journal of Art and Design Education, 24(3), pp. 231-242.

Lewis, T. (2012) The Aesthetics Of Education. Theatre, Curiosity And Politics In The Work Of Jacques Rancière and Paulo Freire (London, Bloomsbury).

Lewis, T. (2013) Jacques Rancière's Aesthetic Regime In Democratic Education, Journal of Aesthetic Education, 47(2), pp. 49-70.

McDonnell, J. (2016) Is it, 'All About Having an Opinion'? Challenging the Dominance of Rationality and Cognition in Democratic Education via Research in a Gallery Setting, International Journal of Art and Design Education, 10.1111/jade.12107

McDonnell, J. (2014a) Re-imagining the Role of Art in the Relationship Between Democracy and Education, Educational Philosophy and Theory, 46(1), pp. 46-58.

McDonnell, J. (2014b) Finding a Place in the Discourse: Film, Literature and the Process of Becoming Politically Subject, Journal of Social Science Education, 13(4), pp. 78-86.

Rancière, J. (2009a) The Emancipated Spectator (London, Verso).

Rancière, J. (2009b) Contemporary Art And The Politics Of Aesthetics, in: B. HinderliterW. Kaizen, V. Maimon, J. Mansoor \& S. McCormick. (eds.) Communities of Sense. Rethinking Aesthetics and Politics (London, Duke University Press).

Rancière, J. (2008) Why Emma Bovary Had To Be Killed, Critical Inquiry, 34(2), pp. 233248.

Rancière, J. (2007) The Future Of The Image (London, Verso).

Rancière, J. (2006) Hatred of Democracy (London, Verso). 
Rancière, J. (2004) The Politics Of Aesthetics (London, Bloomsbury).

Rancière, J. (1999) Dis-agreement: Politics And Philosophy (Minneapolis, MN, University of Minnesota Press).

Rancière, J. (1991) The Ignorant Schoolmaster: Five Lessons In Intellectual Emancipation (Stanford, CA, Stanford University Press).

Rudduck, J. and Fielding, M. (2006) Student Voice And The Perils Of Popularity, Educational Review, 58(2), pp. 219-231.

1. See also Abbs, 2003 for an account of Read's influence on the development of an expressivist paradigm for arts education in schools in the UK in the 1960s and 1970s.

2. Rancière refers in particular to Claude Lanzmann's film Shoah and its representation of the concentration camps to illustrate this point (2007, pp. 126-129).

3. See, for example, his discussion of the work of Virginia Woolf, as well as Henry James and James Joyce (Rancière, 2008, 2004).

4. As opposed, for example, to the 'para-politics of representative democracy or the 'metapolitics' of Marxism (Rancière, 1999, p. 65). 